\title{
Resolving Ambiguity of Some Egyptian Political Jokes Contemporaneous with 2011 Revolution
}

\author{
Hanan A. Ebaid ${ }^{1}$ \\ ${ }^{1}$ Faculty of Arts, Sohag University, Sohag, Egypt \\ Correspondence: Hanan A. Ebaid, Faculty of Arts, Sohag University, Sohag, Egypt. E-mail: hebaid@yahoo.com
}

Received: September 5, 2017 Accepted: October 7, 2017 Online Published: November 2, 2017

doi:10.5539/ells.v7n4p25 URL: http://doi.org/10.5539/ells.v7n4p25

\begin{abstract}
This paper focuses on resolving ambiguous jokes that were contemporaneous with 2011 revolution in Egypt. It observes that some jokes are easily understood by some and are unintelligible to others. The current study is a qualitative descriptive research that depends on collecting and analysing qualitative data. The data is classified into three groups each of which represents a group of ambiguous jokes corresponding to a degree on a proposed scale of specificity. This scale comprises linguistic and socio-pragmatic aspects that contribute to disambiguating such jokes and achieving the humorous effect. It finds that understanding a joke in general and an ambiguous one in particular depends not only on linguistic aspects. It also finds that the integration of the scale of specificity into the analysis proves crucial. The degrees on the scale help explain why a joke is understood by some and incomprehensible to others. Those degrees are relative in that what is deemed as a general degree may be regarded as a specific one to others.
\end{abstract}

Keywords: ambiguity, ambiguous jokes, socio-pragmatic aspects, scale of specificity

\section{Introduction}

The Egyptian people are well known for their sharp sense of humour even in critical circumstances like the 2011 revolution that has been abundant in struggle, bloodshed and suffering. The present study mainly deals with the disambiguation of some Egyptian political jokes contemporaneous with the aforementioned revolution. It attempts to address the following issues. Showing that despite the fact that jokes are essentially meant to be entertaining and humorous, some fail to achieve this. This is sometimes ascribed to a recipient's inability to grasp the full import of a joke because of his/her unfamiliarity with some words or lack of apt socio-pragmatic information needed for its comprehension. Emphasising the interplay between linguistic and non-linguistic elements in understanding many structures such as jokes. Displaying the need for a tool like a scale of specificity that helps explain and interpret an ambiguous joke.

The current paper handles a human aspect that is universal and ubiquitous, namely humor or the humorous effect of jokes attributed to ambiguity. A joke is a phrase or a paragraph with a humorous twist. It can be in many different forms, such as a question or short story. Hocket (1977) holds that "jokes are an art form; specifically a genre of literature." To him, they are "discourses that are laughed at and are repeated from time to time in essentially unchanged form" (pp. 258-259).

Reyes, Buscaldi, \& Rosso (2009) believe that people practise humour as a daily activity. Ambiguity in this case is deliberate and intentional. The humorous effect, that is mostly represented by a laughter, arises as a result of disambiguation or resolving ambiguity. MacDonald, Pearlmutter, \& Seidenberg (1994) maintain that disambiguation involves activating one alternative of a given type that inhibits all others. Yusuf (2011) believes that an indication of the richness of language is when it allows so many meanings and multiple possibilities.

Hudson (2000) states that ambiguity occurs when a linguistic form or expression has two or more meanings. He discerns two main types of ambiguity; lexical and structural. Lexical ambiguity results from the existence of homonyms; instances of a linguistic form having two or more meanings. Thus "bank" may mean a side of a river or a financial institution. These are further subclassified into homophones and homographs. Homonymy is often contrasted with polysemy. Klepousniotou (2002) identifies it as "a single lexical item that has several different but related senses" (p. 206), such as "neck" meaning both the part of the body between the head and the shoulders and the part of a piece of clothing that fits around the neck. Consequently, homonymy signifies 
relatedness of form whereas polysemy exhibits relatedness of meaning.

On the other hand, structural ambiguity happens when difference in meaning is based on grouping of words or grammatical relations (function). The following sentence is an example of grouping ambiguity.

1). I ate chocolate pudding and ice cream.

The word "chocolate" may modify both "pudding" and "ice cream" or only "pudding". In

2). I like music more than you.

There are two interpretations depending on whether the pronoun you functions as subject or direct object. The sentence may mean a. I like music more than you like it, or b. I like music more than I like you.

There can also be syntactic play, or as Chiaro (1992) puts it playing with syntax, which she defines as "play on an ambiguity which can easily occur when sentences contain rank-shifted prepositional groups" (p. 41). One example quoted from Chiaro would suffice to illustrate this type

Child: Mummy, can I go out to play?

Mother: with those holes in your trousers?

Child: No, with the girl next door.

Raskin (1985) proposes an account of verbal humour in general and jokes in particular. For him a single text can be thought of as a joke if it meets the following conditions:

1) The text is compatible, fully or in part, with two different scripts

2) The two scripts with which the text is compatible are opposite in a special sense. (p. 99)

The script is a large chunk of semantic information surrounding the word or evoked by it. It is a cognitive structure internalized by the native speaker and it represents the native speaker's knowledge of a small part of the world.

Raskin's script-based semantic theory has two main components. The first recognizes the meaning of the word in the lexicon. The second ... is represented by the combinatorial rules. Their basic function is to combine the meanings of words in a sentence with the semantic interpretation of the whole sentence. The combinatorial rules should produce two or more different interpretations for an ambiguous sentence. Some of the requirements that should be fulfilled by this theory are: to detect and mark the source(s) of ambiguity and to disambiguate a sentence in an extralinguistic context comprising a sentence and some non-linguistic aspects pertinent to its interpretation.

This highlights the concept that disambiguation involves linguistic as well as non-linguistic dimensions, the reference to which could be of prime importance in order to reach the intended meaning. Some of these dimensions may be represented by social, cultural or pragmatic elements shared by certain groups. Thus, Moore \& Carling (1982) argue that linguistic expressions are meaningful and interpretable in many cases when they are related to different stores of knowledge which enable us to make sense of these expressions. Langacker (1987) adopts an encyclopedic view of semantics whose core concept is the rejection of a sharp distinction between semantics and pragmatics or rather between linguistic and extralinguistic knowledge. Similarly, Marmaridou (2011) states that socio-pragmatics generally refers to the study of the external pragmatic factors affecting language use. She further notes that socio-pragmatics focuses on "the ways in which the non-linguistic environment affects language use" (p. 78).

It should be noted that jokes requiring both linguistic and extralinguistic aspects for their understanding may in many cases be inaccessible to many. Teresa \& Roura (1995) claim that Social and cultural factors have an important say in the development of humour across cultures.

Chiaro (1992) argues that "jokes in which socio-cultural references cross-cut play on language are the most difficult of all to render in another language" (p. 87)

Shafik (2007) deals with some Egyptian political, economic and social jokes whose interpretation may depend on phonological, lexical, syntactic or socio-pragmatic play. For him, socio-pragmatic aspects are divided into playing with implication and playing with the rules of conversation. The former relates to a recipient's ability to reach an implicit rather than an explicit meaning of a joke. Gabr (1986) argues (as cited in Shafik, 2007) that what a joke implies may be more important for understanding a joke than what it says. The latter type corresponds partly to Grice's cooperative principle and its maxims. Shafik focuses on one of its components, namely to avoid ambiguity. Many jokes are deliberately ambiguous. 
Shafik employs the concept of pragmalinguistic and socio-pragmatic aspects in a general sense. He analyses many jokes in terms of these factors but does not refer to their gradability. The present paper assumes that such elements are gradable from being general to specific. Understanding the aspects related to a degree on the proposed scale of specificity contributes to resolving an ambiguous joke, hence the humorous effect. The following sections are meant to provide a satisfactory answer to the main question of the paper of how to disambiguate a joke through the use of the scale of specificity.

\section{Method}

The current study is a qualitative descriptive research that depends on collecting and analysing qualitative data. The data is represented by some jokes that accompanied the outburst of the Egyptian revolution whose main events took place in 2011. The jokes are collected from several online sources such as forums and blogs. Each of them includes many jokes the fewest of which are ambiguous.

The data consisting of thirteen jokes is classified into three groups each of which includes some ambiguous jokes corresponding to a degree on a proposed scale of specificity.

This scale comprises two main dimensions; the linguistic and the socio-pragmatic. Disambiguating a joke may require the understanding of the intended meaning of one or more of its words only. In this case, ambiguity may be lexical or syntactic. For some jokes, integrating socio-pragmatic background information becomes indispensable for their comprehension. These two dimensions are correlated with what the researcher calls the scale of specificity. This scale can be represented as follows:

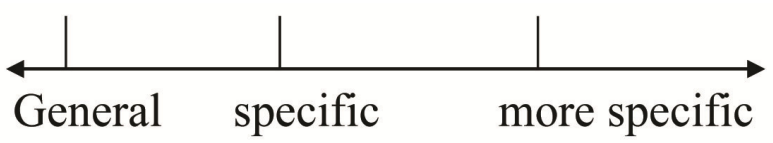

It is divided into different degrees of specificity ranging from the general to the more specific. If a joke's disambiguation relies heavily on the linguistic dimension, then the general degree on the scale of specificity is likely to be activated. By contrast, when the reference to some socio-pragmatic information is essential for understanding a joke, a specific degree on the scale is instigated. It should be noted that the degrees on the scale are relative and variable. Thus, what is considered as a specific degree for some may be deemed a general degree for others. For instance, in joke 7 below, the two possible meanings of the verb /yimši/ "to walk" or "to abandon a place" may be easily understood by one group of people. In this case, a general degree operates. If only the first meaning is accessible to another group, then knowing the second meaning constitutes a specific degree on the scale. Some preceding studies like Shafik's (2007) and Gabr's (as cited in Shafik, 2007) lack such a principled way of explaining ambiguity. Thus, Shafik refers to socio-pragmatic aspects in a general manner. He regards jokes entailing such aspects discretely, i.e., every analysed joke is an independent entity that is not linked to other similar examples.

The section to follow focuses on the analysis of relevant data in terms of the scale of specificity explained above and the statement of the results obtained.

\section{Results and Discussion}

The analysed jokes are classified into three main groups. Group A requires a general degree on the scale of specificity. Group B necessitates a specific degree while understanding group C jokes calls for a more specific degree. The jokes are transliterated to English using the symbols in the Appendix A.

\section{Group A}

1). țalaba r'̄̄s 'albarlamān 'almiṣri fatḥi surūr min arra'īs mubārak kitābat hițāb wadāe lišša 'b 'almiṣri . qāla mubārak " huwa -šša 'b rāiỵ̣ fīn?"

The chairman of the Egyptian parliament Fathi Sorour asked President Mubarak to write a farewell letter to the Egyptian people . Mubarak said "Where are they going?"

To borrow Raskin's term, there are two possible scripts evoked by the word / wadā \% Is it Mubarak or people to leave. The first represents the unmarked, i.e., the most frequent and expected. The second is the marked, i.e., the less expected one. Usually, the marked script specifies the funny climatic twist of a joke.

2). mufăğa'a mudhila

kul -il'ağyāl rāḥit lilğ̄̌š. 'ị̣na alğ̄il 'illi -lğ̄̌s ğāluh.

Astonishing surprise 
All generations went to the army; we are the generation that the army came to.

This joke is an example of lexical ambiguity. The verb/ rāhit / is polysemous as it can either mean "to go" or "to join" the army. There is a distinction drawn between generations before and after January 25, 2011 revolution. On February 11, 2011 the Supreme Council of the Armed Forces was designated to govern Egypt by its departing President Mubarak. This explains how the army came to the generation of January 25 revolution.

3). qāla šāhid 'ayān fi 'arwiqat wazarat 'attarbiya wa -tta 'līm 'anna 'imtiḥanāt 'addūr -ittāni mu' ağğala li' ağal gayr musamma bisabab suqūṭ 'anniẓām

An eye witness in the halls of the ministry of Education said that supplemental exams are postponed indefinitely due to the failure (overthrow) of the regime that needs more time to study.

This joke is also an illustration of lexical ambiguity. The word / suqūt / either means "to fail an exam" or "to be overthrown" which is the intended one.

4). yatahadat 'aḥad -il'ašḩāṣ 'ila qanāt 'alğazīra wa yaqūl lahum 'annahu baqiya fi-lmaydān 'ahad 'ašara yawman wa lam yu țihi 'ạ̣ad 'ağinda

Someone is talking angrily to Al-jazeera TV channel and telling them that he has been staying in the square for 11 days but has not been given a diary yet.

The word /'ağinda/ is a homonym as it may refer to "a diary" or "a political agenda". The former is usually used by Egyptians as synonymous with a diary. The latter sense is identified in Wikipedia as "the set of goals of an ideological group." which has widely spread ... during and after the main events of the revolution. It has specially been manipulated by opposing sides which have exchanged accusations of attempting to execute specific plans.

5). A: tam ḩațf arra'īs mubārak wa -lfidya ḩamas malayīn. yuhadid 'alhăạtifūn bisakb 'albanzīn 'alayh wa ḥarquh law lam yatim daf' ahā. nağma' 'altabaru' āt hal tuhị 'almušăraka?

B: bikam fi-lmutawasit?

A: min hams 'ila 'ašarat litrāt banzīn

A: "President Mubarak is kidnapped and the ransom is 5 million. If it is not paid, the kidnappers threaten to pour gasoline and burn him. We collect donations, would you like to participate?"

B: "On the average, how much?"

\section{A: "From 5 to 10 liters of gasoline."}

The word /tabaru āt/ donations is ambiguous as it may refer to the ransom or to gasoline, the first of which is unmarked as a ransom is usually the money paid to set a kidnapped person free. The second referent, which is marked, represents twist of the joke.

6). ' arāda mubārak 'attarašuḥ marra 'uhra li-ri' āsa. qāla lahu 'ạ̣aduhum "hal 'anta mağnūn?"

mubārak: "hal hada šart ḍarūri?"

Mubarak wanted to be re-nominated for presidency. Someone said to him, "Are you crazy?" Mubarak wondered whether this had been a necessary requisite.

Syntactically, the first question is a Yes/No question whose answer should either be affirmative or negative. The second question is contrary to expectations and indicates pragmatically Mubarak's assumption that the first question constitutes a requisite that should be fulfilled. Consequently, the first question has two opposite senses, the second of which brings the humorous effect.

7). yimkin yukūn miš ‘̄awiz yimši. qulūluh yāḩud taksi.

Perhaps he does not want to walk. Tell him to take a taxi.

This joke involves lexical ambiguity as the verb / yimši / is polysemous. It either means "to walk" or "to abandon Egypt". Some languages like Arabic and Italian are said to be null- subject languages. Radford (2004) states that "finite verbs in a language like Italian can have either overt or null subjects" (p. 13). According to the context of this joke, the null subject of the verbs /yimši/ and /yāhud/ designates Mubarak. Protestors kept saying / miš hanimši huwa yimši/ or we are not leaving, he should leave and step down. The final part of the joke gives the impression that the "to walk" sense of the verb is the intended one. However, the "to leave and step down" sense is more salient as these words circulated widely prior to Mubarak's stepping down.

8). sami' 'alqad̄āfi 'anna mubārak kāna fi ġaybūba wa s'ala 'aḥad wuzarā’ih kam tab ud gaabūba 'an libya 
Gadaffi heared that Mubarak was in a coma. He asked one of his ministers how far coma had been from Libya.

According to Oxford Dictionary, the preposition "in" may be used to show a state or condition or to refer to a point within an area or a space. The preposition "in" in this case is polysemous. Gadaffi's question exemplifies his widely established reputation as a weird person.

\section{Group B}

To reiterate, Group B jokes require a specific degree on the scale of specificity. Group B jokes appeal to large circles of people as the socio-pragmatic aspects associated with such jokes are accessible to them.

9). 'ašša b 'attūnisi 'arāda -lḥayā fastağāba -lqadar. 'ašša b 'almiṣri 'arāda -lḥayā fawağadahā 'ala taradud 11255 'ufuqi

The Tunisian people sought life and fate responded. The Egyptian people sought life and found it at the frequency of $11255 \mathrm{H}$.

The word /'alhayā/ is a homonym as it refers to two words having the same form but quite distinct meanings. The first identifies "life" as the initial part of the joke is based on a very well known poem. The homonym in the second part specifies an Egyptian TV channel. In spite of the fact that the source of ambiguity is the lexical item "life", however, disambiguating the joke depends heavily on socio-pragmatic aspects.

10). A: "'îh ra'yak fi-ltaġyīr?"

Mubārak: "di sunnat 'alḥayā"

A: "law kida līh miš rādi titnaḥha?"

Mubārak: "la' anni fard"

Someone: "What do you think about change?"

Mubarak: "It is the law of nature."

Someone: "If so why do not you step down?"

Mubarak: "Because I am fard" and not sunna.

Two of the possible senses of the word /sunna/ are; the nature of things or words and practices of Prophet Mohammed (pbuh). This joke will be comprehensible only when some socio-pragmatic and cultural dimensions are referred to. Mubarak's reply implies his insistence on keeping his position as the president.

11). A: "'īd mubārak ya ğirğis"

ğirğis: "ḥata -l'a yād baqit bita tu"

A: "Blessed feast, Girgis."

Girgis: "Even feasts have become his."

The word / mubārak/ is a homonym. It either specifies a greeting expression exchanged at some social or religious celebrations in the Arab world or refers to the former Egyptian President Hosni Mubarak. The second participant's reply represents the marked script and the joke's funny twist.

\section{Group C}

A highly specific degree on the scale is needed in order to successfully interpret jokes belonging to this category.

12). suzān mubārak taštari ḥiṣa fi- rrašīdi -lmizān li-tağhīz sandwitšāat ḥalāwa li- 'awladha

Susan Mubarak buys a share in Al-Rasheedy Al-Mizan to make Egyptian confectionery sandwiches for her sons.

Ambiguity here lies in the use of the NP / sandwitšăt halāwa/ Egyptian confectionery sandwiches. There are two opposite scripts stimulated by this phrase. The unmarked is of a mother making confectionery sandwiches for her sons while the marked one implies that her sons are imprisoned ${ }^{4}$. If one is not familiar with the socio-pragmatic aspects pertinent to this phrase, the second script becomes inaccessible. As a result, proper appreciation of the joke fails. Such phrases and structures are considered idiomatic expressions as their meaning does not depend on the literal meaning of its words. The whole expression is treated as one single unit with a specific import.

13). 'iḩtafat' alqulal 'alqināwi min -assūq laḥzat 'i lān tanaḥi ḥusni mubārak

Once Husni Mubarak's stepping down was announced, Qenawi drinking pots disappeared from markets.

In this joke, the NP / 'alqulal/ "clay pots that Egyptians particularly in rural areas used to have for drinking water" has two senses; explicit and implicit. The former literally means "drinking pots made from clay" while 
the latter is figurative. At the departure of someone who is unwelcome, it is often said /niksar qulla warāh/ "we break a drinking pot behind him". When this is done, it is believed that he will not return. The disappearance of Qinawi drinking pots is justifiable as people were assumed to have broken them once Mubarak's stepping down was announced. The intended meaning of the word is reached only when the relevant socio-pragmatic aspects are activated. The next part is the conclusion which comments on the importance of the findings of this paper.

\section{Conclusion}

The main concern of this paper is the attempt to overcome the inability to comprehend a joke due to the lack of some socio-pragmatic aspects. This paper aims at highlighting the strong bond between linguistic and non-linguistic elements in explaining some structures which are primarily linguistic. Through the analysis of some ambiguous jokes, it has been found out that, in many cases, the intended meaning is not reached unless proper reference to relevant socio- pragmatic aspects is made. This strengthens the significance of an encyclopedic view of semantics.

The integration of the scale of specificity into the analysis proves crucial. The degrees on the scale help explain why a joke is understood by some and incomprehensible to others. Those degrees are relative in that what is deemed as a general degree may be regarded as a specific one to others. Usually, jokes with a general degree are correlated, to a considerable degree, with linguistic aspects. Thus, ambiguities in jokes belonging to the general degree are usually lexical or syntactic. The more we move to the right, the more specific a degree on the scale becomes. In this case, the role of socio-pragmatic factors is pivotal in resolving an ambiguity.

This paper also shows that the difficulty of translating certain jokes whether they are ambiguous or not resides in the lack of one-to-one equivalence of terms or expressions reflecting highly specific socio-pragmatic dimensions between two languages. To overcome this problem, a translator may use one of translation procedures such as adaptation, borrowing or paraphrase. In the translation of (13), for instance, the expression "clay pots that Egyptians particularly in rural areas used to have for drinking water" is a paraphrase of the Egyptian word /qula/ while "Qenawi" exemplifies borrowing.

\section{End notes.}

1). There is a well-known poem by the Tunisian poet Aboul-Qacem Echebbi whose first line is translated as

When people seek life one day Fate must respond.

This poem is conceived as a sincere expression of people's wish to have a free and dignified life against injustice and tyranny. During the Tunisian and the subsequent revolutions in many Arab countries, people kept reciting this verse line.

2). Fard and sunna are two Islamic key terms for Muslims worldwide. They are also understood by non-Muslims in countries inhabited by Muslim population such as the Arab world. In the online Arabic Dictionary of Meanings, fard is defined as "A religious duty that is commanded by God." It is obligatory. If a fard like praying or fasting is not performed by someone, he is sinful and deserves God's punishment.

3). This is also cited in the previously mentioned source. It should be noted that unlike fard, If a sunna, e.g. fasting every Monday and Thursday, is not carried out, one wouldn't be sinful.

4). /yākul 'īš wi halāwa/ "to eat bread and confectionery" is a commonly used expression among Egyptians when reference is made to an imprisoned person.

5). The adjective /qināwi / describes a thing that belongs to Qena, an Egyptian Governorate which is famous for making objects from clay such as drinking and cooking pots.

\section{References}

Chiaro, D. (1992). The language of jokes: Analyzing verbal play. London: Routledge. https://doi.org/10.4324/9780203327562

Hockett, C. F. (1977). Jokes. In C. F. Hockett (Ed.), The view from language: Selected essays (pp. 257-289). Athens: The University of Georgia Press.

http://al-3jeeb.blogspot.com/2011/02/blog-post_10.html

http://en.wikipedia.org/wiki/Agenda

http://en.wikipedia.org/wiki/Untranslatability.

http://forums.fatakat.com/thread1272545

http://forums.fatakat.com/thread2465723 
http://lite.almasryalyoum.com/lists/39044/

http://www.albawabhnews.com/1518906

http://www.masrawy.com/ketabat/ArticlesDetails.aspx?AID=91970\&ref=hp

http://www.nmisr.com/vb/showthread.php?t=253249

http://www.safrah.com/showthread.php?t=228

https://ar-ar.facebook.com/note.php?note_id=151019124956272

https://www.almaany.com/ar/dict/ar-ar/wنّة//

https://www.almaany.com/ar/dict/ar-ar/فرض//

Hudson, G. (2000). Essential introductory linguistics. Oxford: Blackwell.

In. 2014. In Oxfordlearnersdictionaries.com

Klepousniotou, E. (2002). The processing of lexical ambiguity: Homonymy and polysemy in the mental lexicon. Brain and Language, 81, 205-223. https://doi.org/10.1006/brln.2001.2518

Langacker, R. W. (1987). Foundations of cognitive grammar, Vol.1, Theoritical prerequisites. Stanford: Stanford University Press.

MacDonald, M. C., Pearlmutter, N. J., \& Seidenberg, M. S. (1994). Lexical nature of syntactic ambiguity resolution. Psychological Review, 101, 676-703. https://doi.org/10.1037/0033-295X.101.4.676

Marmaridou, S. (2011). Pragmalinguistics and sociopragmatics. In B. Wolfarm \& N. R. Norrick (Eds.), Foundations of Pragmatics (pp. 77-106). Berlin: Mouton De Gruyter. https://doi.org/10.1515/9783110214260.77

Moore, T., \& Carling, C. (1982). Language understanding: Towards a post- chomskyan linguistics. New York: St. Martin's Press. https://doi.org/10.1007/978-1-349-16895-8

Radford, A. (2004). English syntax: An introduction. Cambridge: University Press. https://doi.org/10.1017/CBO9780511841675

Raskin, V. (1985). Semantic mechanisms of humor. Dordrecht: D.Reidel Publishing Company.

Retrieved June 8, 2014, from http://www.oxfordlearnersdictionaries.com/definition/english/in_l? $q=$ in

Reyes, A., Buscaldi, D., \& Rosso, P. (2009). An analysis of the impact of ambiguity on automatic humour recognition. Paper presented at the Proceedings of the 12th International Conference on Text, Speech and Dialogue, 162-169. https://doi.org/10.1007/978-3-642-04208-9_25

Shafik, A. (2007). Verbal play in Egyptian political jokes: Pragmalinguistic and sociopragmatic perspective. Retrieved from http://www.wata.cc/forums/showthread.php?6854-Verbal-Play-in-Egyptian-Political-Jokes

Teresa, M., \& Roura, S. (1995). Syntactic ambiguity as a device in British humour. Revista Alicantina de Estudios Ingleses, 8, 209-228. https://doi.org/10.14198/raei.1995.8.18

www.arabic.cnn.com/2011/facebook/2/22/libya.facebook/index.html

نكت_الثورة/2ww.masreat.com

Yusuf, H. (2011). The importance of being ambiguous or the sin tax of ignoring syntax [Blog post]. Retrieved from http://www.sandalaproductions.com/Blog/26-the-sin-tax-of- ignorning-syntax.aspx 


\section{Appendix A}

\section{Transliteration Symbols of Arabic Letters}

, i

b ب

$\mathrm{t}$

$\underline{\mathrm{t}}$

g ج

h $\tau$

h $\dot{\tau}$

d $د$

$\underline{\mathrm{d}} \dot{j}$

r J

z j

s w

s ش

ص ص

ض

t b

z

c $\varepsilon$

$\dot{\mathrm{g}} \dot{\varepsilon}$

$\mathrm{f}$ ف

q

k s

$1 \mathrm{~J}$

$\mathrm{m}$ ?

n ن

h。

w 9

y

\section{Short Vowels}
a
i
$\mathrm{u}$

\section{Long Vowels Compound Vowels}

$\begin{array}{lllll}\bar{a} & \overline{1} & \bar{u} & \text { aw } & \text { ai }\end{array}$

The DIN 31635 standard for the transliteration of the Arabic alphabet is followed.

\section{Copyrights}

Copyright for this article is retained by the author, with first publication rights granted to the journal.

This is an open-access article distributed under the terms and conditions of the Creative Commons Attribution license (http://creativecommons.org/licenses/by/4.0/). 